\title{
Which factors shape macrozoobenthic communities in tufa springs? Results from Austrian meteogene travertine-depositing sites
}

\author{
Jean-Pierre Bednar $(\mathbb{D} \cdot$ Manuela Trobej $\cdot$ Michael Schagerl $\cdot$ Johann Waringer
}

Received: 10 November 2016/Revised: 24 April 2017/ Accepted: 29 April 2017/Published online: 20 May 2017

(C) The Author(s) 2017. This article is an open access publication

\begin{abstract}
By studying 14 travertine-depositing springs all over Austria, we hypothesized the existence of (1) key elements of the physical and chemical template ultimately defining the structure of macroinvertebrate taxa composition and (2) a specific, travertine-associated macrozoobenthic taxa community in an environment shaped by ongoing deposition of calcium carbonate and the ever-changing limestone structures thereby created. For testing these hypotheses, we measured 29 geological and limnochemical parameters and collected benthic macroinvertebrates on travertine, coarse and fine particular organic matter microhabitats in a spring and autumn sampling run. The results identified four parameters significantly shaping taxa composition: sinter coverage, total phosphorous, oxygen concentration and the Langelier saturation index. The macroinvertebrate community was predominantly composed of stygobiontic taxa from groundwater refugia and of immigrated generalists that prefer the stable conditions offered in spring
\end{abstract}

Electronic supplementary material The online version of this article (doi:10.1007/s10750-017-3228-x) contains supplementary material, which is available to authorized users.

Handling editor: Eric Larson

J.-P. Bednar · M. Trobej · M. Schagerl · J. Waringer ( $\square)$ Department for Limnology and Bio-Oceanography, University of Vienna, Althanstraße 14, 1090 Vienna, Austria

e-mail: johann.waringer@univie.ac.at habitats. We found only few species and specialists separating study sites, the majority being well-known spring- and headwater-dwelling species without adaptation to high carbonate precipitation or association with travertine. Nonetheless, carbonate precipitation leads to higher structural heterogeneity and provides a range of new niches, which contribute to broader ranges of taxonomic diversity.

Keywords Tufa $\cdot$ Springs $\cdot$ Zoobenthos . Limnochemistry $\cdot$ Carbonate precipitation

\section{Introduction}

Hydrogeologically, springs are defined as places where groundwater emerges to the land surface, thereby creating isolated running water habitats with stable conditions and high environmental heterogeneity (Hynes, 1970; Odum, 1971; Botosaneanu, 1998; Sherwood \& Sheath, 1998; Barquin \& Scarsbrook, 2008; Kløve et al., 2011). In fact, Ward (1992) pointed out that a high degree of physical and chemical constancy exists in spring habits, especially if associated with deep aquifers. Under such circumstances, the mean annual water temperature is close to the mean annual air temperature at the spring location. The overall geological situation, however, strongly modifies annual fluctuations of water temperature 
(Van der Kamp, 1995). In addition to the latter, a constant flow regime and stable substrates are the primary factors structuring the biotic communities of springs (Ward, 1992). Due to the transition between terrestrial and aquatic zones, springs can be considered as patchy, highly structured multiple 3-way ecotones which create interfaces to groundwater and surface water (Townsend, 1989; Roca \& Baltanás, 1993; Cantonati et al., 2006; Scarsbrook et al., 2007; Gerecke et al., 2011). Combining many different microhabitats and substrate types, springs are hot spots of structural and biotic diversity where groundwater species mix with surface water biota and terrestrial or wetland taxa (Illies \& Botosaneanu, 1963; Stanford et al., 1994; Ferrington, 1995; Hahn, 2000; Hoffsten \& Malmqvist, 2000). In addition, surface water and neighbouring terrestrial ecosystems also control springs, thereby creating a three-way zone of interaction (Scarsbrook et al., 2007; Pokorny et al., 2010).

The unique conditions creating meteogene travertine springs greatly add to this structural diversity: sinter terraces, cascades, dams and walls are shaped by calcium carbonate precipitation (tufa) where the main $\mathrm{CO}_{2}$ source originates from the soil by root respiration (Merz \& Zankle, 1991; Pentecost \& Viles, 1994; Wright, 2000; Glazier, 2009). This mechanism is in contrast to thermogene travertine deposition in hot water springs where $\mathrm{CO}_{2}$ originates from hydrolysis and oxidation of reduced carbon, thereby providing extreme habitats inhabited only by highly specialized hyperthermophilic biota such as bacteria and archaea (Ford \& Pedley, 1996).

Although springs are identified as hotspots of biodiversity in numerous studies, they are not considered in the European habitat directive with the only exception of "petrifying springs with tufa formation" (Cratoneurion; Code * 7220) (EU HD, 1992). This earmarks tufa springs as highly vulnerable and threatened habitats. Despite this, the current insights into key abiotic variables characterizing tufa springs and the biota inhabiting them are poor and rather limited (Cantonati et al., 2006). In the present study, we aim to provide new insights into tufa spring ecology. Specifically, (1) we wanted to elucidate the role of the physical and chemical template of meteogene springs in structuring macroinvertebrate communities for providing a better understanding of this highly endangered habitats, and (2) to relate this information with macrozoobenthic taxa composition in an environment shaped by ongoing deposition of calcium carbonate and the ever-changing limestone structures thereby created.

\section{Materials and methods}

\section{Study sites}

Located in Central Europe, Austria is a predominantly mountainous country where the alpine chain can be split into the Central Eastern Alps, consisting mainly of gneiss and slate, and the Northern and Southern Limestone Alps. With a total area of $84,000 \mathrm{~km}^{2}$, the country is part of the temperate Central European climate zone influenced by the Atlantic in the west and by continental effects in the east. Sampling sites were located in the Alps and the Vienna basin (a sedimentary basin between the Eastern Alps and the Carpathian Mountains), and originally consisted of 25 different travertine-depositing springs and headwaters. Fourteen of these sites were classified as active travertine deposition sites where sinter terraces, cascades, dams and walls were currently shaped by calcium carbonate precipitation, and were therefore selected for a detailed study (Fig. 1). Sampling site geology ranged from sandstone (e.g. WOE, LUT, HOC sites) and carbonate (e.g. TES, EDL, LAP) to dolomitic (e.g. POE, ZOO) and molasse formations (e.g. LIN site); nival flow regimes dominated, with pluvial and complex regimes present only at sites WOE and LIN, respectively; discharge varied from $1 \mathrm{~s} \mathrm{~s}^{-1}$ (ALM) to $7261 \mathrm{~s}^{-1}$ (DAN). Slopes at the sampling sites ranged from $3.8 \%$ (POE) to $63.7 \%$ (PRE) (Table 1).

Sampling in the field and laboratory work

All parameters were measured twice (spring: April to May 2014; autumn: September 2014: Table 1) except slope, elevation, geology, flow regime and calcium carbonate precipitation. A synopsis of the physicochemical dataset is provided as supplementary material (Table S1).

\section{Choriotopes}

After photographical documentation of each sampling site, the following three choriotopes were mapped and their percentage areas estimated: (1) travertine 


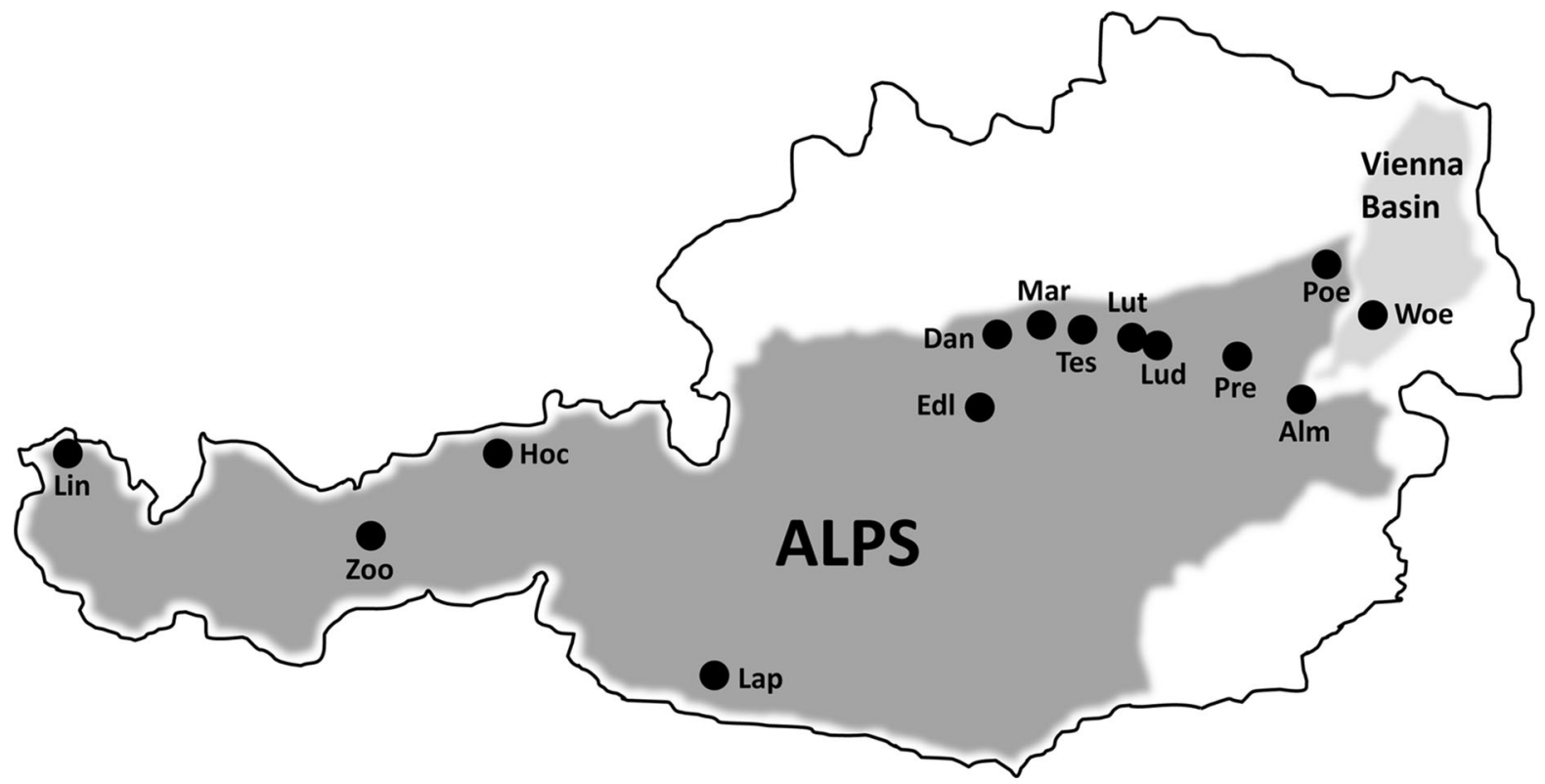

Fig. 1 Map of Austria showing the location of the 14 sampling sites located in the Alps and the Vienna Basin. (Woe Woellersdorf, Lut Lunz top, Lud Lunz down, Poe Poellerbach, Alm Almassysschloessl, Zoo Alpenzoo Innsbruck, Hoc
Hochalmtal, Lin Lingenau, Pre Preinmuehle, Mar Maria Neustift, Dan Dandlgraben, Lap Lappenbach, Tes Teschengraben, $E d l$ Edlbach)

Table 1 Overview of sampling locations, elevations and dates including geographical coordinates of all sites

\begin{tabular}{|c|c|c|c|}
\hline Site, elevation (m a.s.1.); slope (\%) & ID & Sampling dates & Coordinates \\
\hline \multirow[t]{2}{*}{ Woellersdorf, Lower Austria $(417 ; 12.2)$} & \multirow[t]{2}{*}{ WOE } & 20 May 2014 & $\mathrm{~N} 47.8567^{\circ}$ \\
\hline & & 19 Sep 2014 & E $16.1364^{\circ}$ \\
\hline \multirow[t]{2}{*}{ Maiszinken, Lunz (top), Lower Austria (732; 18.5) } & \multirow[t]{2}{*}{ LUT } & 22 May 2014 & $\mathrm{~N} 47.861343^{\circ}$ \\
\hline & & 15 Sep 2014 & E $15.067526^{\circ}$ \\
\hline \multirow[t]{2}{*}{ Maiszinken, Lunz (down), Lower Austria $(698 ; 21.3)$} & \multirow[t]{2}{*}{ LUD } & 22 May 2014 & $\mathrm{~N} 47.8599^{\circ}$ \\
\hline & & 15 Sep 2014 & E $15.0666^{\circ}$ \\
\hline \multirow[t]{2}{*}{ Side arm of the Poellerbach, Alland, Lower Austria $(431 ; 3.8)$} & \multirow[t]{2}{*}{ POE } & 26 May 2014 & $\mathrm{~N} 48.055684^{\circ}$ \\
\hline & & 19 Sep 2014 & E $16.025906^{\circ}$ \\
\hline \multirow[t]{2}{*}{ Almassysschloessl next Schloeglmuehl, Lower Austria $(635 ; 20.8)$} & \multirow[t]{2}{*}{ ALM } & 31 May 2014 & $\mathrm{~N} 47.699812^{\circ}$ \\
\hline & & 18 Sep 2014 & E $15.904347^{\circ}$ \\
\hline \multirow[t]{2}{*}{ Alpenzoo Innsbruck, Tyrol $(696 ; 26.3)$} & \multirow[t]{2}{*}{$\mathrm{ZOO}$} & 22 Jun 2014 & $\mathrm{~N} 47.283133^{\circ}$ \\
\hline & & 09 Sep 2014 & E $11.398982^{\circ}$ \\
\hline \multirow[t]{2}{*}{ Hochtalalm, Tyrol $(892 ; 14.6)$} & \multirow[t]{2}{*}{ HOC } & 23 Jun 2014 & $\mathrm{~N} 47.549090^{\circ}$ \\
\hline & & 09 Sep 2014 & E $11.888078^{\circ}$ \\
\hline \multirow[t]{2}{*}{ Lingenau, Vorarlberg $(587 ; 52.4)$} & \multirow[t]{2}{*}{ LIN } & 24 Jun 2014 & $\mathrm{~N} 47.444036^{\circ}$ \\
\hline & & 09 Sep 2014 & E $9.907163^{\circ}$ \\
\hline \multirow[t]{2}{*}{ Preinmuehle next Schwarzau, Preintal, Lower Austria $(747 ; 63.7)$} & \multirow[t]{2}{*}{ PRE } & $01 \mathrm{Jul} 2014$ & $\mathrm{~N} 47.794759^{\circ}$ \\
\hline & & 18 Sep 2014 & E $15.660054^{\circ}$ \\
\hline \multirow[t]{2}{*}{ Maria Neustift, Upper Austria $(473 ; 25.8)$} & \multirow[t]{2}{*}{ MAR } & 04 Jul 2014 & $\mathrm{~N} 47.930808^{\circ}$ \\
\hline & & 22 Sep 2014 & E $14.610769^{\circ}$ \\
\hline
\end{tabular}


Table 1 continued

\begin{tabular}{|c|c|c|c|}
\hline Site, elevation (m a.s.1.); slope (\%) & ID & Sampling dates & Coordinates \\
\hline Dandlgraben next Maria Neustift, Losenstein, Upper Austria (440; 47.2) & DAN & $\begin{array}{l}\text { 04 Jul } 2014 \\
22 \text { Sep } 2014\end{array}$ & $\begin{array}{l}\mathrm{N} 47.930454^{\circ} \\
\text { E } 14.451295^{\circ}\end{array}$ \\
\hline Lappenbach next Stein, Drauntal, Carinthia $(723 ; 37.1)$ & LAP & $\begin{array}{l}15 \text { Jul } 2014 \\
11 \text { Sep } 2014\end{array}$ & $\begin{array}{l}\mathrm{N} 46.727105^{\circ} \\
\text { E } 13.040664^{\circ}\end{array}$ \\
\hline Teschengraben, Lower Austria $(546 ; 24.6)$ & TES & $\begin{array}{l}25 \text { Jul } 2014 \\
15 \text { Sep } 2014\end{array}$ & $\begin{array}{l}\mathrm{N} 47.926322^{\circ} \\
\text { E } 14.800572^{\circ}\end{array}$ \\
\hline Edlbach next Spital am Phyrn, Upper Austria $(675 ; 11.6)$ & EDL & $\begin{array}{l}25 \text { Jul } 2014 \\
22 \text { Sep } 2014\end{array}$ & $\begin{array}{l}\mathrm{N} 47.673229^{\circ} \\
\text { E } 14.35100^{\circ}\end{array}$ \\
\hline
\end{tabular}

(sinter), (2) coarse particular organic matter $>1 \mathrm{~mm}$ (cPOM; e.g. leaves and twigs) and (3) fine particular organic matter $<1 \mathrm{~mm}$ (fPOM; fine detrital particles).

Carbonate precipitation rates

To estimate calcium carbonate precipitation rates, metal washers were mounted randomly in the stream bed of each sampling site during the first sampling. After exposure, the incrusted washers were recovered using a mobile metal detector in September 2014. The rates were calculated by measuring the height of the surface deposition of the recovered washers, using a binocular (ZEISS SteREO Lumar.V12). Discs were vertically mounted with paper clips, and the thickness of the incrustations was measured using the ZEISS ZEN Software (blue edition, 2011). Arithmetic means of incrustation thickness measurements (5 random measurements per washer) and the exposure time in the field enabled us to calculate precipitation rates per year $\left[\mathrm{mm} \mathrm{a}^{-1}\right]$.

\section{Physico-chemical parameters}

Oxygen concentration, conductivity, $\mathrm{pH}$ and water temperature were measured on site by electrodes; alkalinity, hydrogen carbonate and free carbon dioxide were measured by standard titration (Hütter, 1994). Slope was measured using a flexible tube water level. Flow velocities were obtained by using the tracer method with methylene blue after Pomeisl (1953), and discharge measured using the velocity-area method. The Langelier Saturation Index (LSI), a measure of scaling saturation of water with calcium carbonate (Tchobanoglous \& Burton, 1991), was calculated based on $\mathrm{pH}$, TDS or conductivity, $\mathrm{Ca}^{2+}$ and $\mathrm{HCO}_{3}{ }^{-}$ concentrations, and water temperature (Lenntech 2015).
Water samples were taken at each site (triplicates), and part of the water filtered through Whatman GFF (Glass microfiber filters, $47 \mathrm{~mm} \varnothing$ ) syringe filters for nutrient and major cation/anion analyses; the unfiltered part was used for total phosphorus (TP) analyses; samples were transported in an ice box to the laboratory at the Department of Limnology and Bio-Oceanography for analyses. Major cation and anion concentrations were obtained by Ion chromatography (Metrohm Compact IC 761) or photometrically (HACH-LANGE DR 2800).

\section{Geology and sky openness}

Geological information was obtained from the database of the Federal Bureau of Geology, and the riverine landscape and flow regime typology according to Wimmer et al. (2000) was used for the site descriptions (details in Appendix 1). Sky openness (percentage of free open sky above every sampling site as proxy for the canopy coverage) was obtained by using a NIKON Coolpix 4500 camera with NIKON Fisheye Converter Lens FC-E8 $0.21 \mathrm{x}$ and the software "gap light analyser” (GLA, v2) after Frazer et al. (1999).

\section{Macroinvertebrates}

For the invertebrate community, 27 subsamples per site were taken. The number of samples per choriotope reflected the site-specific area of each choriotope. We used 2 methods: (1) a syringe-tube-combination and a bottomless $250 \mathrm{ml}$ bottle, its neck modified by adding a rubber lip for travertine microhabitats (sampling area $=12.6 \mathrm{~cm}^{2}$ ) and (2) a syringe-tube-combination and a bottomless $250 \mathrm{ml}$ bottle without rubber lip for fPOM and cPOM substrates (sampling area $=12.6 \mathrm{~cm}^{2}$ down to $2 \mathrm{~cm}$ sediment depth; sampling volume $=25.1$ 
$\mathrm{cm}^{2}$ ). For cPOM substrates, leaf and twig sections not covered by the sampling tube were cut with scissors; this procedure enabled us to sample the cPOM material in depth. Preservation was done in the field with $75 \%$ ethanol. Organisms were sorted from organic matter using hand nets ( $200 \mu \mathrm{m}$ mesh size), identified under a microscope (ZEISS SteREO Lumar.V12) and identified using standard keys (Nilsson, 1996a, b; Reynoldson \& Young, 2000; Bauernfeind \& Humpesch, 2001; Eggers \& Martens, 2001; Glöer, 2002; Graf \& Schmidt-Kloiber, 2002; Glöer \& Meier-Brook, 2003; Janeček, 2003; Bellmann, 2010; Waringer \& Graf, 2011). For macroinvertebrate abundance, the 27 samples per site were pooled and site-specific abundance estimated using six frequency classes $[0=$ absent; $1=$ single; $2=$ rare (2-3 specimens); $3=$ medium $(4-6$ specimens $)$; $4=$ abundant $(5-12$ specimens); $5=$ very abundant ( $>12$ specimens)]. The dominance classification of macroinvertebrates closely follows the classes defined by Schiemenz (in Müller, 1984): 16-35.9\% of the total sample $=$ dominant, $>36 \%=$ eudominant. EPT taxa richness was given as percentage of Ephemeroptera, Plecoptera and Trichoptera taxa in relation to total taxa number per site. Steadiness was calculated by dividing the number of sites with species A by the number of sites and multiplying with 100 (Müller, 1984).

Statistical analysis and graphics

Statistics were carried out in $\mathrm{R}$ (version 3.1.3, $\mathrm{R}$ development Core Team, Vienna, Austria). Non-metric multidimensional scaling (nMDS) was calculated with $\mathrm{R}$ function metaMDS using the dissimilarity matrix as input and two dimensions; the function for the MDS was monoMDS. The dissimilarity matrix was calculated with taxa frequencies using the Bray-Curtis index (functions vegdist and hclust), and the best agglomeration method was chosen (function cophentic). A mantel test was carried out to find the optimum number of clusters. The number of random starts was 100 , and the maximum number of iterations was 2000 ; the start searched for the best previous solution.

For analysis of similarities (ANOSIM; R package vegan), we compared the $\mathrm{R}$ statistic to a set of repeatedly calculated $R^{\prime}$ values resulting from a random shuffle of our sites. The percentage of $\mathrm{R}$ surpassing $\mathrm{R}^{\prime}$ yielded the $p$ value for the $\mathrm{R}$ statistic ( -1 to 1 ) with positive numbers indicating similarities within sites, but differences between sites.
For linking site-specific taxa frequency (including rare taxa) with environmental parameters, a direct gradient analysis was performed ( $\mathrm{R}$ function labdsv). Based on gradient lengths (axis 1: $\mathrm{SD}=2.68$, axis 2: $\mathrm{SD}=2.79$ ), a subsequent constrained correspondence analysis (CCA) was suggested. We used R function cca, based on taxa and $\mathrm{z}$-standardized environmental data. After automatic forward selection ( $\mathrm{R}$ function ordistep), collinear variables were eliminated. The second CCA run included only parameters identified as significant in the forward selection; we retained only variables with inflation factors $<10$ for further analysis (=4 from originally 25 variables: $\mathrm{O}_{2}$ concentration, TP, sinter coverage and LSI). Using log-scaled frequency classes for invertebrate abundance ensured unimodal responses to environmental variables. Permutation tests ( $\mathrm{R}$ function anova.cca) tested for significance of the model, of the first axis and of selected environmental parameters.

For indicator species analyses (ISA), the R function IndVal was used. Based on within-group taxa frequency and abundance, indicator value indices between taxa and groups were calculated; for groups with highest values, significance was verified by permutation tests (999 permutations). Indicator values were high when taxa were more abundant within a single group, compared to the other groups identified by nMDS.

\section{Results}

Environmental and structural parameters

Except at stations EDL and LUT, within-site areal proportion of sinter increased during the summer while cPOM and fPOM areas were highly variable in their proportions. The highest sinter coverage was estimated for DAN in spring (93\%). Water temperature varied from $7.2{ }^{\circ} \mathrm{C}$ (PRE) to $15.8^{\circ} \mathrm{C}$ (HOC). At eleven out of 28 site visits, water temperature ranges between 11 and $13{ }^{\circ} \mathrm{C}$ were noted. Conductivity values ranged from around $260 \mu \mathrm{S} \mathrm{cm}^{-1}$ (PRE) to $1000 \mu \mathrm{S} \mathrm{cm}^{-1}$ (ZOO), and the majority of the $\mathrm{pH}$ measurements from 8.2 to 8.3. Lowest (7.6) $\mathrm{pH}$ values were measured in LUT and LUD. The LSI was always well above 0 , indicating that water was supersaturated with $\mathrm{CaCO}_{3}$, with a high probability of carbonate precipitation. Calcium carbonate precipitation rates mostly varied between 0.8 and $2.0 \mathrm{~mm}$ per year. 

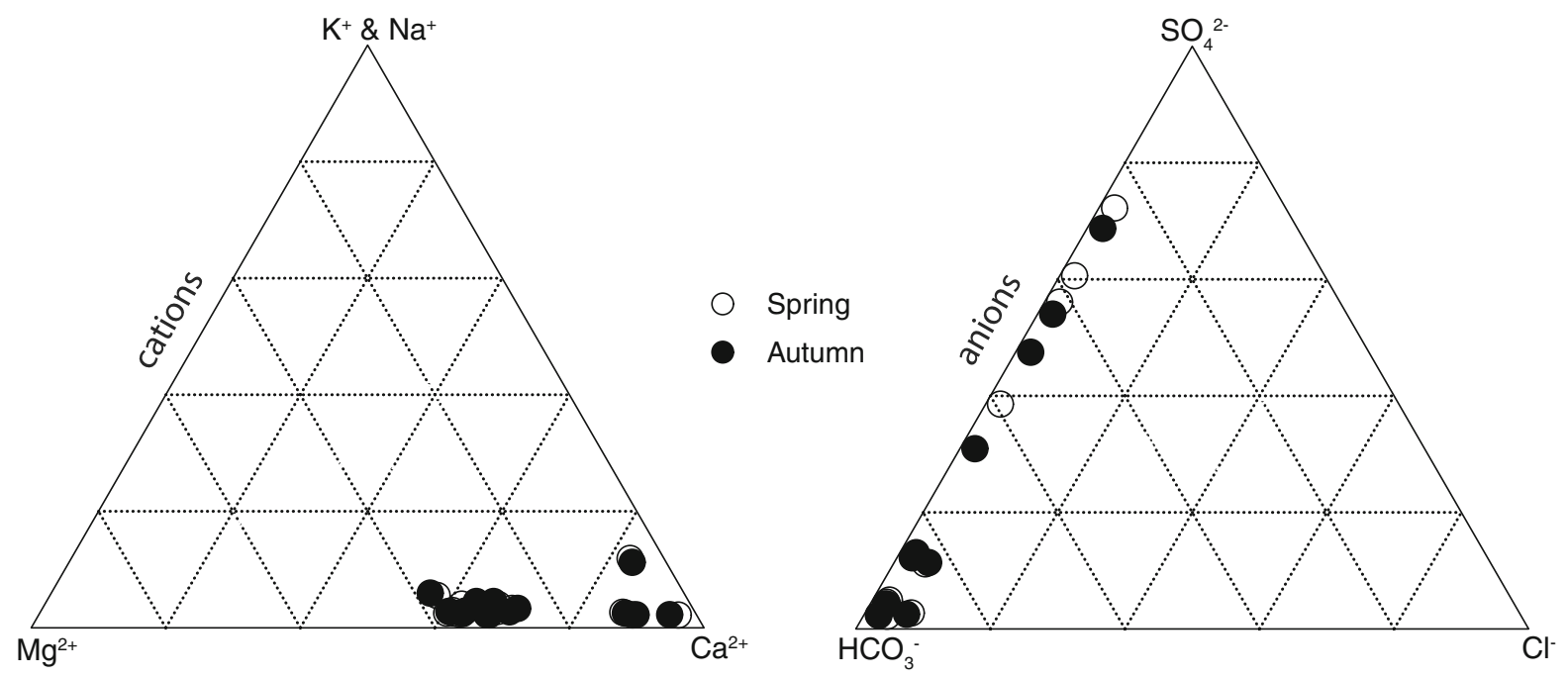

Fig. 2 Ternary plots of major anions/cations for each sampling station. Full circles indicate the autumn, open circles the spring samples. The values are standardized to 1 . Dashed lines indicate intervals of 0.2 units

We generally observed higher values for $\mathrm{Ca}^{2+}$ than for $\mathrm{Mg}^{2+}$ or $\mathrm{Na}^{+} / \mathrm{K}^{+}$(Fig. 2). The highest $\mathrm{Ca}^{2+}$ values were measured at ZOO $\left(164.7 \mathrm{mg} \mathrm{l}^{-1}\right)$, together with peak concentrations of $\mathrm{SO}_{4}{ }^{2-}$ and $\mathrm{Mg}^{2+}$. The lowest $\mathrm{Ca}^{2+}, \mathrm{Na}^{+}, \mathrm{K}^{+}$and $\mathrm{Mg}^{2+}$ were measured at PRE, combined with the lowest conductivity and water temperature. We observed always comparably low $\mathrm{Cl}^{-}$concentrations next to higher $\mathrm{HCO}_{3}{ }^{-}$and $\mathrm{SO}_{4}{ }^{2-}$ amounts. LIN showed the highest $\mathrm{Cl}^{-}, \mathrm{Na}^{+}$and $\mathrm{K}^{+}$ values next to lowest TP concentrations, combined with the highest calcium carbonate precipitation rates $\left(4.15 \mathrm{~mm} \mathrm{a}^{-1}\right)$. In accordance with major ions, nutrients did not show seasonal differences. Highest SRP concentrations were measured at DAN (mean $=65.6 \mu \mathrm{g} \mathrm{l}^{-1}$ ), with the remaining headwater sites ranging from below detection limit to $6.1 \mu \mathrm{g} 1^{-1}$. At DAN station, we also noticed the highest TP $\left(179.1 \mu \mathrm{g}^{-1}\right)$ and $\mathrm{NO}_{2-} \mathrm{N}\left(12.6 \mu \mathrm{g} \mathrm{l}^{-1}\right)$ concentrations next to the highest discharge $\left(7261 \mathrm{~s}^{-1}\right)$ and $\mathrm{pH}$ (8.3). Highest $\mathrm{NO}_{3-} \mathrm{N}$ values were measured in $\mathrm{LIN}$, lowest in HOC.

Fauna

\section{Taxa composition}

We identified 1491 specimens belonging to 50 macroinvertebrate taxa (Appendix 1). Taxa number was highest in Ephemeroptera (7 taxa), Trichoptera (7 taxa) and Diptera (12 taxa). Within Diptera, the dominant family was Chironomidae with the most abundant subfamily of Orthocladiinae; Ibisia marginata (Athericidae) was only found in spring at LAP in low abundance. Within the Ephemeroptera, Baetidae were abundant, whereas Heptageniidae and Ephemeridae were rare. In Plecoptera, Protonemura sp. was by far the most abundant genus, whereas Brachyptera risi was found only sporadically. In Trichoptera, Rhyacophila pubescens occurred most frequently. Potamophylax cingulatus, Crunoecia kempnyi and Plectrocnemia geniculata were rarely found. The only representative of the order Odonata was Cordulegaster bidentata, collected in WOE and LUT/LUD during spring. Coleoptera were generally rare and represented by only two families: Elmidae (Elmis sp., Limnius volckmari) and Staphylinidae.

The crustacean Gammarus fossarum was one of the most abundant species and was present at nearly all sampling sites, whereas the groundwater-associated genus Niphargus sp. occurred only at the EDL station in spring. In molluscs, four different Bythinella species were identified in this study (B. cylindrica, B. opaca opaca, B. bavarica and B. austriaca austriaca).

Generally, taxa richness varied with season. At six sites, the spring taxa numbers were higher than in autumn, whereas at six sites the reverse was true. In POE and LIN, the taxa numbers were equal in both seasons. Ecdyonurus sp., Ephemera danica, Nemoura 


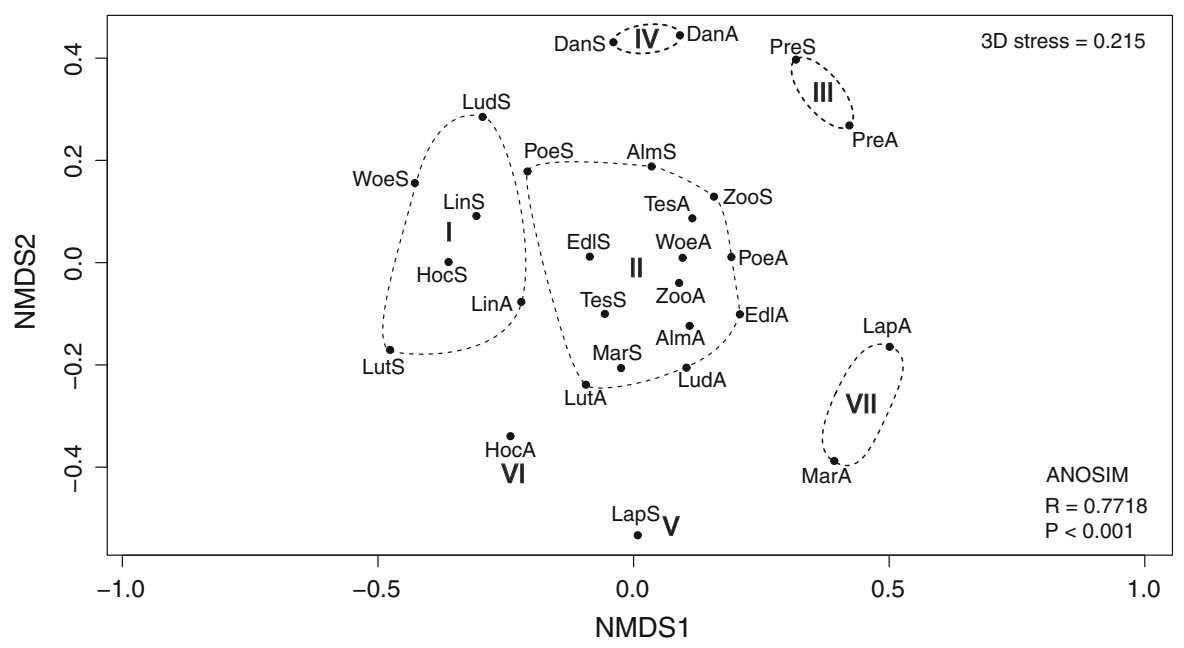

Fig. 3 Ordination of site scores by non-metric multidimensional scaling (nMDS). Site acronyms are explained in Table 1. $S$ spring sampling, A autumn sampling. Dashed lines indicate

sp., Brachyptera risi, Leuctra braueri, Crunoecia kempnyi, Plectrocnemia geniculata, Ibisia marginata, Krenosmittia sp., Niphargus sp., Bathyomphalus contortus, Bythinella cylindrica, B. bavarica and B. opaca opaca were only present in spring samples. The number of taxa throughout the study period was highest at POE station (21 taxa) and lowest at DAN and TES (8 taxa) (Appendix 1). EPT taxa richness varied between $0.0 \%$ at PRE and $61.5 \%$ at LUD station. Steadiness was highest in Gammarus fossarum and the chironomid subfamily Orthocladiinae (92.9\%), as well as in genera Protonemura and Simulium $(85.7 \%)$. On the other hand, steadiness was as low as $7.1 \%$ in Ephemera danica, Nemoura sp., Brachyptera risi, Potamophylax cingulatus, Plectrocnemia geniculata, Rhyacophila s.str., some Diptera taxa (e.g. Ceratopogonidae, Muscidae, Ibisia marginata, Krenosmittia sp.), Crustacea taxa (Niphargus sp., Macrocyclops sp., Isopoda) and Bythinella spp.

Macroinvertebrate communities

Non-metric multidimensional scaling (nMDS) identified seven site groups, explaining $59.6 \%$ of variance (stress $=0.215, P<0.001$; Fig. 3 ), and a subsequent analysis of similarities (ANOSIM) confirmed highly significant differences between those groups $(R=0.7718 ; P<0.001)$. seven groups based on cluster analysis. Stress values and ANOSIM results are shown at right

Group I, a cluster of six samples (WOES, LUTS, LUDS, HOCS, LINS, LINA; Fig. 3), is characterized by low $\mathrm{pH}$ values and a high LSI (Table 2). The stonefly genus Protonemura sp. and Gammarus fossarum are eudominant ( $>36 \%$ of the total; Schiemenz in Müller, 1984), chironomid subfamilies Tanypodinae and Orthocladiinae dominant at these locations (Table 2).

Group II consists of 14 datasets $(=50 \%$ of the samples) obtained from five sites with both summer and autumn samples (POE, ALM, ZOO, TES and EDL) and 4 additional sites where only either the summer or the autumn sample were included (Fig. 3). Low discharge and high conductivity defines the abiotic setting of this group, combined with high water temperatures and sky openness (POE), $\mathrm{SO}_{4}{ }^{2-}$ and $\mathrm{Mg}^{2+}$ (ZOO) and increased $\mathrm{O}_{2}$ supply (EDL). Slope was very low (POE), as was discharge and SRP in ALM. No eudominant macroinvertebrate taxa were found; Crenobia alpina, G. fossarum, Protonemura sp., Simulium sp. and subfamily Orthocladiinae were dominant (Table 2).

Only one or two sites were included in Groups III to VI (Fig. 3). Group III is characterized by the lowest water temperature, conductivity (Table 2 ), sky openness, $\mathrm{Na}^{+}, \mathrm{K}^{+}, \mathrm{Mg}^{2+}$, TIC, $\mathrm{HCO}_{3-}$ and LSI values of all study sites; in Group $\mathrm{V}, \mathrm{O}_{2}$ and TP were lowest (Table 2). In contrast, SRP and TP concentrations 


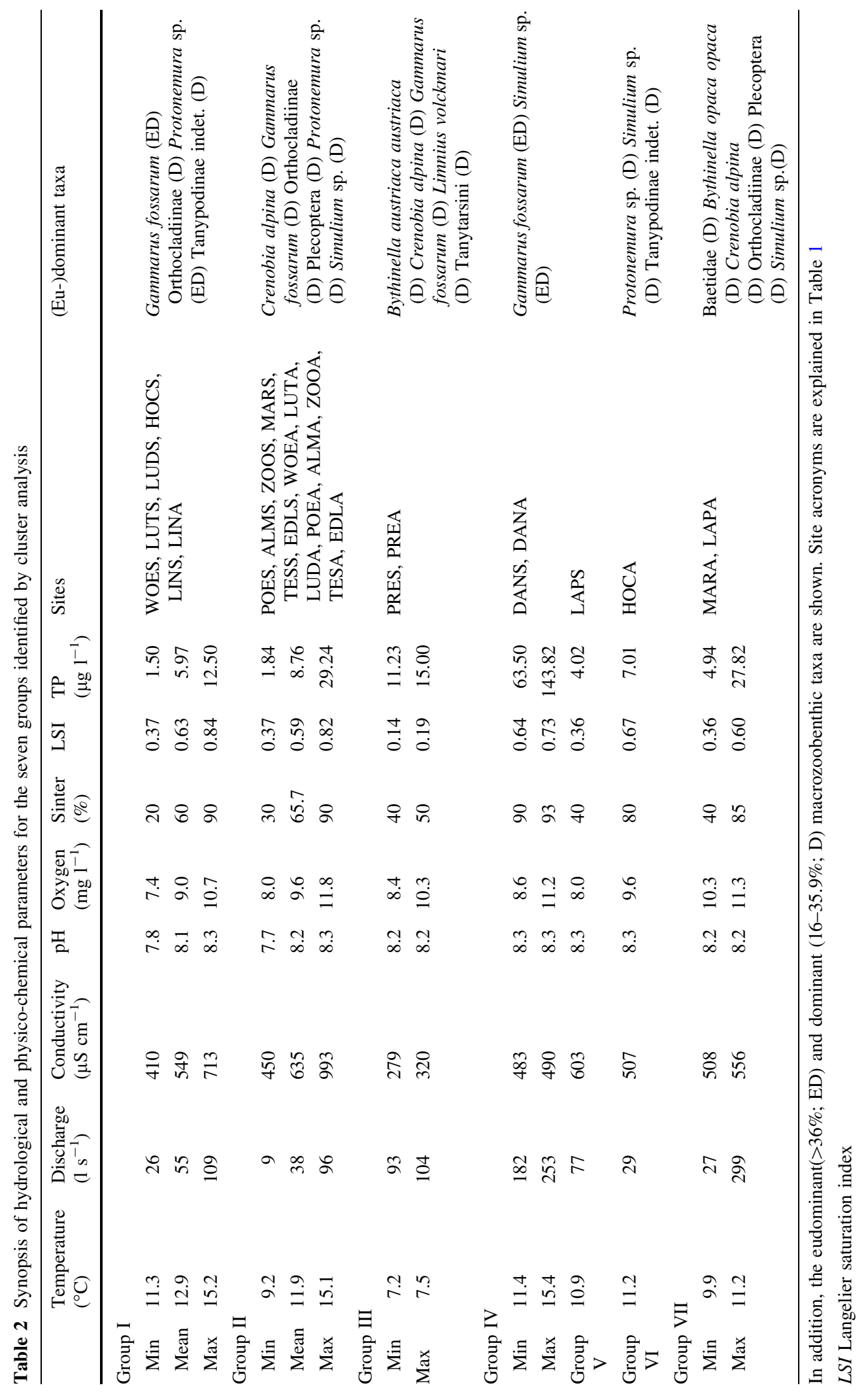


were highest in Group IV (Table 2). With respect to macroinvertebrate communities, Bythinella austriaca austriaca was dominant and only present in Group III (Table 2), whereas Gammarus fossarum was eudominant in Group IV which is in line with the high TP, sinter coverage and oxygen supply of this cluster. In Group V, macroinvertebrates were collected only in low abundance (Appendix 1), but dominant taxa such as Protonemura sp., Simulium sp. and the chironomid subfamily Tanypodinae were abundant in Group VI (Table 2).

Group VII includes the autumn samples of MAR and LAP stations (Fig. 3), when discharge was high (Table 2). The gastropod Bythinella opaca opaca, only collected at LAP station, was dominant in autumn. Other dominant taxa include Crenobia alpina and Simulium sp. (Table 2). At MAR, more than twice the taxa number (9) were collected in spring compared to autumn (4) (Appendix 1).

A subsequent constrained correspondence analysis resulted in a significant model explaining $14.8 \%$ of the total variance in the dataset $(P<0.001)$; the summary statistics are shown in Table 3. A total of 25 environmental parameters were included and four parameters significantly contributing to the species pattern $(P<0.05)$ retained:sinter coverage, TP, $\mathrm{O}_{2}$ and Langelier saturation index. Figure 4A displays the first two canonical axes including the complete taxa set affiliated to the 7 groups identified by nMDS, and the four significant environmental parameters. LSI was high and sinter coverage low in Groups I, II and VI, whereas Groups VII and III were characterized by low LSI and sinter coverage; in fact, in group III, we observed the lowest LSI and sinter coverage of all study sites. In Group V, $\mathrm{O}_{2}$ and TP were lowest. In contrast, TP concentrations were highest in Group IV, as was sinter coverage and TP (Fig. 4A).
After defining site groups, a subsequent indicator species analysis (ISA) was performed. In contrast to dominance classification which yields information on in-group taxa abundance, ISA explores indicator value indices between groups. In Fig. 4B, the dots indicate the locations of the three indicator species in the ordination, whereas the pie charts depict the relative abundance of indicator species within the 7 groups defined by nMDS. Bythinella austriaca austriaca was collected only at station PRE in Lower Austria and was identified as indicator species for Group III (Indicator value: 100.0\%). Indicator species for Group IV is Gammarus fossarum (Indicator value: $36.2 \%$ ) and, with lower indicator values, in groups I, II and III. Simulium sp. (Indicator value: $40.1 \%$ ) is indicative for Group VI (HOCA), and also for groups II, IV and VII and I.

\section{Discussion}

The environment

Habitat characteristics of meteogene travertine-depositing head water streams are mainly driven by bedrock characteristics shaping the lithology of the aquifer (Van der Kamp, 1995). Parameters such as water temperature, alkalinity, $\mathrm{pH}$ and conductivity consistently illustrate the limnochemical fingerprints and the high buffer capacity of carbonate systems present at almost all sites of the present study (Table 2). The impact of lithology becomes evident when comparing our data with findings originating from Buntsandstein formations where Hahn (2000) measured comparable water temperature ranges, but lower $\mathrm{pH}$ and conductivity values at 33 travertine springs in the Pfälzerwald mountains (Germany). This

Table 3 Summary statistics of the constrained correspondence analysis

\begin{tabular}{|c|c|c|c|}
\hline & Axis 1 & Axis 2 & Axis 3 \\
\hline Eigenvalues & 0.353 & 0.291 & 0.205 \\
\hline Species-environment correlations & 0.913 & 0.964 & 0.887 \\
\hline Cumulative percentage variance of species-environmental relation & 8.1 & 14.8 & 19.8 \\
\hline Sum of all eigenvalues & 4.362 & & \\
\hline Test of significance of the first canonical axis: $P$ value & $<0.001$ & & \\
\hline Test of significance of all canonical axes: $P$ value & $<0.001$ & & \\
\hline
\end{tabular}


Fig. 4 Constrained correspondence analysis. A CCA plot of the axis 1 and 2 showing site groupspecific cluster split and the retained $(P<0.05)$ environmental parameters [sinter, total phosphorous (TP), oxygen concentration $\left(\mathrm{O}_{2}\right)$ and Langelier saturation index (LSI)]. The two axes explain $14.8 \%$ of total variance. B Indicator species in the ordination (black dots) and pie charts showing the relative abundances in the seven site groups defined by nMDS

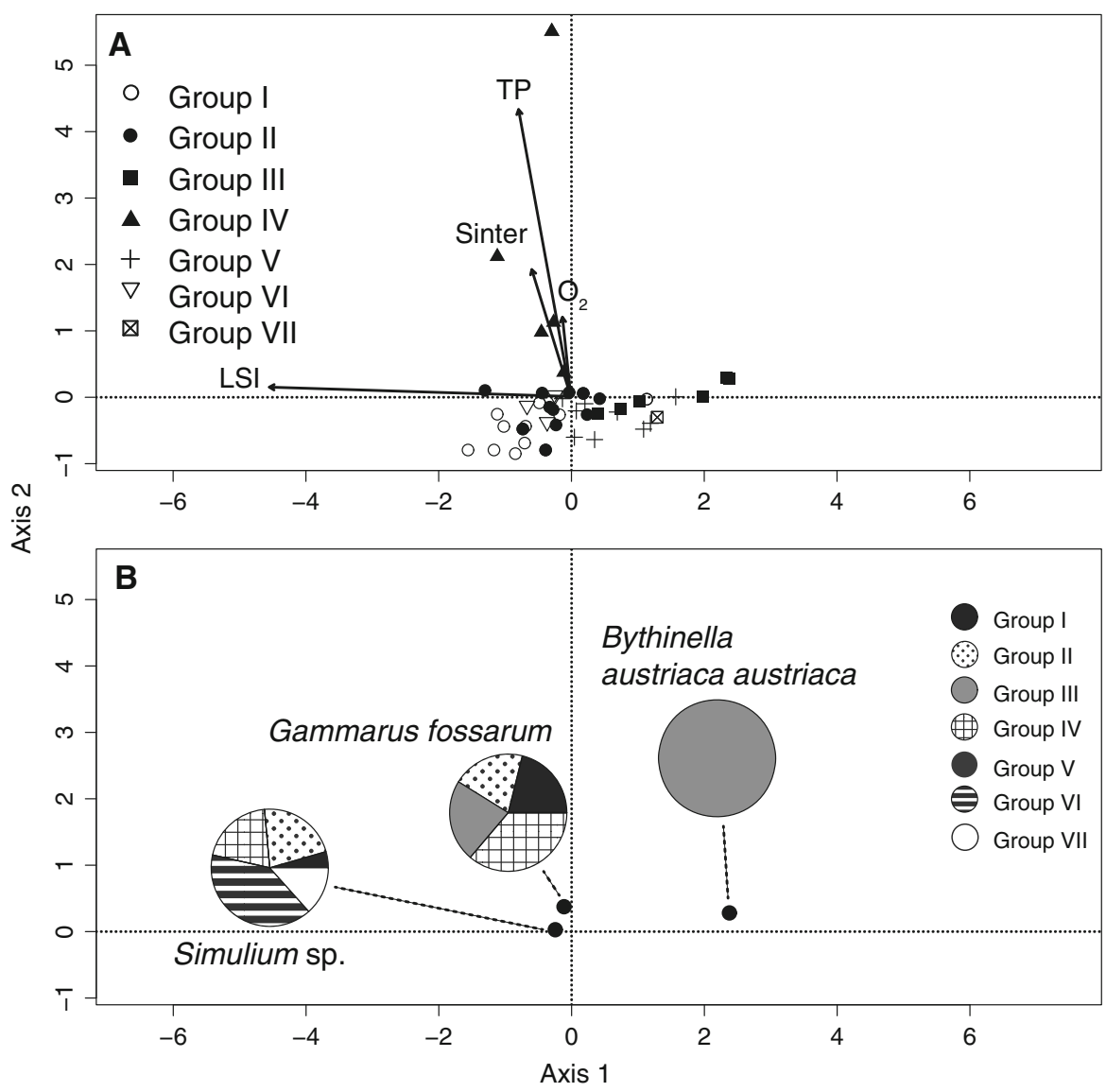

region is subject to more acidic conditions due to sulphuric and nitrogenous components in the bedrock. Comparable data for $\mathrm{pH}, \mathrm{Ca}^{2+}$ and $\mathrm{Mg}^{2+}$ concentrations as reported in the current study were also found in Germany by Arp et al. (2001), whereas higher conductivity values were obtained for the landslide area "Schütt" in Carinthia (Austria), yet with similar pH ranges (Staudacher \& Füreder, 2007). Sanders \& Rott (2009) and Rott et al. (2012) studied LIN, ZOO and HOC stations in Tyrol a few years ago; their measurements of water temperature, conductivity, $\mathrm{pH}$, sulphate and chloride were in the range of our data. Also, $\mathrm{Ca}^{2+}$ and $\mathrm{Mg}^{2+}$ at the LIN station were comparable, but the values at ZOO station obtained by Sanders \& Rott (2009) were somewhat higher. With respect to $\mathrm{pH}$, data from the United Kingdom (Pentecost, 1991) were in the same range as our study, combined with broader ranges of water temperature as well as much lower values for alkaline earth metals.

The 14 investigated travertine-depositing springs were always highly saturated with oxygen. TP amounts were especially elevated at DAN due to private estates closely surrounding the site. In northern Germany, Martin \& Brunke (2012) measured $\mathrm{O}_{2}$ saturation levels at 170 lowland springs between 47 and $61 \%$ and $\mathrm{TP}$ values from 21 to $41 \mu \mathrm{g} \mathrm{l^{-1 }}$. However, TP values were significantly lower (1 to $12 \mu \mathrm{g} \mathrm{l}^{-1}$ ) at springs in the Italian Alps (Cantonati et al., 2006). Interestingly, the latter authors also reported that snow melt and heavy rains heavily increased DOC concentrations which was in line with our findings where autumn rains increased DOC concentrations at some stations (maximum $4.17 \mathrm{mg} \mathrm{l}^{-1}$ ). 
Taxa composition

Little is known about the faunal distribution in travertine-depositing springs. Despite the high structural heterogeneity of such sites, some studies show evidence for taxonomic impoverishment (especially Coleoptera), without any characteristic species (Zollhöfer, 1997; 1999; Martin \& Wischniowsky, 2014). High rates of encrustation at active travertine surfaces may be a hostile setting for organisms without any adaptation, but the sinter provides also a surface for encrusting algae and detritus, which serve as food source (Pentecost, 2005).

During this study, 50 taxa of different taxonomic levels were identified, some of them in young developmental stages therefore not identifiable down to species level. The most abundant taxon was the amphipod Gammarus fossarum, which was present in nearly all sites except for TES. The rheophilous $G$. fossarum is ubiquitous in freshwater and also a dominant taxon in other travertine-depositing habitats (Hahn, 2000; Pentecost, 2005; Křoupalová et al., 2011). In terms of functional feeding groups, Gammarus is a typical detritus feeder and shredder playing a major role in the organic matter cycle and often serving as prey for other organisms (Karaman \& Pinkster, 1977; Kelly et al., 2002a). Moreover, this genus is also a predator, especially of mayfly nymphs of the family Baetidae (Kelly et al., 2002b), which was the most abundant family of Ephemeroptera in our survey. Another gammarid amphipod, Niphargus sp., was identified but was rare compared to G. fossarum. Niphargus is a typically stygobiontic genus that often migrates into spring habitats. Due to its groundwater adaptation, this genus tolerates acidic conditions in water enriched with $\mathrm{CO}_{2}$. Interestingly, a shift in the presence of these two taxa was recognized along environmental gradients. G. fossarum is dominant over Niphargus sp. at good water buffering capacity and nutrient-rich conditions. This is reversed at $\mathrm{pH}$ lower than 6 (Hahn, 2000). Glazier (1991) observed that freshwater crustaceans were positively affected by lowered osmotic stress at high alkalinity conditions and good $\mathrm{Ca}^{2+}$ supply needed for exoskeleton formation; this observation can explain the dominance of this taxon in our study.

Chironomids were also found at nearly all sites during this study. Chironomids of spring habitats are typically high in terms of both abundance and taxa richness, making them good bioindicators for water quality (Gerecke et al., 1998). This family includes a range of organic matter-dwelling taxa such as Tanypodinae and Tanytarsini, which inhabit muddy fPOM sediments, and subfamily Orthocladiinae associated with bryophytes adjoining mud and gravel (Lencioni et al., 2012). This distribution pattern is in line with other studies (Thienemann, 1924, 1934; Hahn, 2000; Staudacher \& Füreder, 2007; Lencioni et al., 2011; Omelková et al., 2013).

A further abundant family was the blackflies (Simuliidae), whose larvae and pupae are restricted to running waters. This family is typical in travertine cascades during summer (Pentecost, 2005). All species of this taxon are filter feeders and attach to planar surfaces (e.g. rocks, stones, sinter, vegetation), as they tolerate high water velocities. There is some evidence that the travertine encrustation facilitates attachment (Minckley, 1963). The larvae normally filter particles from the water column using their cephalic fans (Nilsson, 1996b). The genus Simulium was present in 19 out of 28 samplings and also inhabits travertine-depositing springs in Germany (Hahn, 2000). In our study, higher abundance was always combined with higher discharge.

Stoneflies are typical for oxygen-saturated lotic systems. The order Plecoptera was represented by four different taxa. The most abundant by far was Protonemura, a typical detritus and algae feeder. Stoneflies are poor flyers, which limits dispersal distances and promotes local populations (Nilsson, 1996a; Bo et al., 2009). The genera Leuctra and Nemoura are also present in this study and, next to Protonemura, are known to feed on calcifying algae (Pentecost, 2005). Further studies in Germany (Hahn, 2000) and Austria (Staudacher \& Füreder, 2007) found similar patterns.

Rhyacophila pubescens is a highly specialized cold-stenothermic caddisfly that shows a postglacial distribution restricted to travertine spring brooks in alpine limestone areas of Central Europe (Pitsch, 1993; Engelhardt et al., 2011); it is only found when travertine is present (Pentecost, 2005). It was the only species in our investigation associated exclusively. $R$. pubescens occurs at altitudes from $160 \mathrm{~m}$ to more than $2000 \mathrm{~m}$ (Coppa et al., 2012), which is in range of the altitudes where our sampling sites were located. It was the most abundant caddisfly and present at 6 out of the 14 sites. This species was also observed in travertine spring habitats of the Western Carpathian Flysch belt 
(Křoupalová et al., 2011), but it was missing in similar habitats of Austria and Germany (Hahn, 2000; Staudacher \& Füreder, 2007), where it was replaced by Plectrocnemia geniculata.

\section{Macroinvertebrate communities}

The cluster analysis based on the taxa inventories yielded seven significant groups. The sites within these groups are seasonally and geographically well mixed. The composition of eudominant and dominant taxa differs between groups, with less overlap of generally abundant taxa. With few exceptions, the overall ranges of environmental data in general were mostly narrow and reflected the inter-habitat homogeneity. All investigated sites can be characterized as rheocrenes with similar structural elements and microhabitat distribution.

The ISA procedure based on the seven groups revealed only 3 highly suitable indicator species, which can be explained by identification problems especially for young development stages of Chironomidae. Bythinella austriaca austriaca, had an indicator value of $100 \%$ for group III, which consists of spring and autumn samples at PRE station, which is characterized by the lowest water temperature and low TP values. Bythinella austriaca austriaca is a freshwater snail with preferences for oligotrophic, stable, cold water springs (Glöer, 2002). Four Bythinella species occur in Austria, all of them are endemic to small areas. B. austriaca austriaca is restricted to Eastern Austria and marked as "near threatened" in the red lists of the European habitat directive (Travnitzky \& Patzner, 2009). Gammarus fossarum is typical for the epirhithral and an eudominant indicator for group IV represented by DAN. Characterized by high $\mathrm{pH}$, water temperature and sinter coverage, this station contains the highest measured SRP and TP concentrations of this study. Gammarus fossarum is ubiquitous in freshwater habitats and known as a typical detritus feeder and shredder. This genus prefers nutrient-rich conditions along with high water buffering capacity, ideally provided by DAN station. Simulium sp. is the only aquatic insect indicator species and indicative for group VI. This group consists of the autumn sample at HOC station with the highest mean LSI value of all sampling sites, also reflected by the second highest calcium carbonate precipitation rate of $2.87 \mathrm{~mm} \mathrm{a}^{-1}$. Development stages of this taxon inhabit only running waters, and the presence of individuals of this family is typical in travertine cascades. Simulium sp. is dominant in group VI, but also eudominant in group IV (DAN station), where the highest discharge of $7261 \mathrm{~s}^{-1}$ was measured.

The results of CCA identified sinter coverage, $\mathrm{O}_{2}$ and TP concentration and the LSI as key variables for the species pattern. Group IV with the detritus feeder Gammarus fossarum as indicator tended to higher TP values, whereas group III with Bythinella austriaca austriaca, which prefers oligotrophic and calcareous conditions, shows tendencies to lower LSI and phosphorus concentrations. This partly agrees with studies that identified acidity and eutrophication (Verdonschot \& Schot, 1987), substratum characteristics (Bonettini \& Cantonati, 1996; Fischer et al., 1998) and hydrochemistry (Mezquita et al., 1999) as key determinants for community assemblages.

The total variance explained by CCA indicates that our set of measured environmental parameters shows trends but is not able to fully explain the whole range of investigated community composition. The complexity of regulating factors for macroinvertebrates is commonly very high (Fischer et al., 1998), including also interspecific resource competition, e.g. on grain size (Bonettini \& Cantonati, 1996) as determinants for spring communities (Fischer, 1996).

The findings of Hahn (2000) suggest that springs are ecotones between low-temperature groundwater habitats and headwaters which are thought to be highly linked with their catchment and diverse in structural heterogeneity. The convergence of these different habitats, paired with the very special hydrochemical characteristics of travertine-depositing springs and headwaters, leads to distinct taxa sets combining both groundwater-dwelling and headwater-dwelling organisms present in other spring areas as well (Hahn, 2000; Staudacher \& Füreder, 2007; Křoupalová et al., 2011; Omelková et al., 2013). A well-known example of a species confined to stable, travertine-depositing springs is the caddisfly Rhyacophila pubescens which was present in 6 out of 14 sites in the present study. Other taxa highlight the island-like character of spring habitats, often combined with limited dispersal rates after postglacial recolonisation: the mollusc $B y$ thinella is strongly restricted to small spring areas with some species being true endemics. Such species greatly rely on the environmental stability provided in 
springs and headwaters and highlight the urgent need for protection of the spring sites themselves, but also the creation of buffer corridors against anthropogenic impacts threatening those fragile travertine spring communities.

\section{Conclusion}

Our study revealed that travertine-depositing springs and headwaters in Austria differed most in terms of increased nutrient concentrations, mainly reflecting anthropogenic impacts. Differences to similar sites in other countries are minimal and can be explained by geology and the catchment. Key parameters for macrozoobenthic community composition are sinter coverage, $\mathrm{O}_{2}$ supply, TP concentration and the LSI. The calcium carbonate precipitation rate merely highlighted trends but could not fully explain the distribution patterns of macrozoobenthos species sets observed. Due to their high potential as indicator species keyed to specific environments, the typical macrozoobenthic composition of springs consists of stygobiontic taxa from groundwater refugia and of immigrated generalists that prefer the stable conditions (e.g. water temperature and buffering capacity). Only a few endemic species (e.g. Bythinella austriaca austriaca, B. opaca opaca, B. bavarica) and travertine spring specialists such as Rhyacophila pubescens accounted for site differences. The rest are wellknown spring- and headwater-dwelling species (e.g. Gammarus and Simulium) without any known adaptation to carbonate precipitation or association with travertine.

Acknowledgements We thank Christoph Bstaendig and Clemens Straganz for assistance in the field. We are also indebted to Simon Vitecek for statistical advice. Special thanks to Hubert Kraill for the chemical analyses, to Rudolf Pavuza and Petra Cech, both Museum of Natural History Vienna, for advice on choosing sampling sites. This work was financially supported by a scholarship of the University of Vienna.

Open Access This article is distributed under the terms of the Creative Commons Attribution 4.0 International License (http:// creativecommons.org/licenses/by/4.0/), which permits unrestricted use, distribution, and reproduction in any medium, provided you give appropriate credit to the original author(s) and the source, provide a link to the Creative Commons license, and indicate if changes were made.

\section{References}

Arp, G., N. Wedemeyer \& J. Reitner, 2001. Fluvial tufa formation in a hard-water creek (Deinschwanger Bach, Franconian Alb, Germany). Facies 44: 1-22.

Barquin, J. \& M. Scarsbrook, 2008. Management and conservation strategies for coldwater springs. Aquatic Conservation 18: 580-591.

Bauernfeind, E. \& U. H. Humpesch, 2001. Die Eintagsfliegen Zentraleuropas (Insecta: Ephemeroptera): Bestimmung und Ökologie. Naturhistorisches Museums Wien, Wien.

Bellmann, H., 2010. Der Kosmos-Libellenführer: alle Arten Mitteleuropas. Kosmos, Stuttgart.

Bo, T., S. Fenoglio, M. J. López-Rodríguez \& J. M. T. de Figueroa, 2009. Phenology of adult Stoneflies (Plecoptera) of the Curone stream (northern Apennines, Italy). Journal of Freshwater Ecology 24: 279-283.

Bonettini, A. M. \& M. Cantonati, 1996. Macroinvertebrate assemblages of springs of the River Sarca catchment (Adamello-Brenta Regional Park, Trentino, Italy). Crunoecia 5: 71-78.

Botosaneanu, L., 1998. Studies in crenobiology - the biology of springs and springbrooks. Backhuys Publishers, Leiden.

Cantonati, M., R. Gerecke \& E. Bertuzzi, 2006. Springs of the Alps-sensitive ecosystems to environmental change: from biodiversity assessments to long-term studies. Hydrobiologia 562: 59-96.

Coppa, G., W. Graf \& H. Tachet, 2012. A revised description of the larvae of three species of the Rhyacophila tristis group: Rhyacophila aquitanica, Rhyacophila pubescens and Rhyacophila tristis (Trichoptera: Rhyacophilidae). Annales de Limnologie-International Journal of Limnology 48: 215-223.

Eggers, T. O. \& A. Martens, 2001. Bestimmungsschlüssel der Süßwasser-Amphipoda (Crustacea) Deutschlands. Lauterbornia 42: 1-68.

Engelhardt, C. H. M., P. Haase \& S. U. Pauls, 2011. From the Western Alps across Central Europe: Postglacial recolonisation of the tufa stream specialist Rhyacophila pubescens (Insecta, Trichoptera). Frontiers in Zoology 8: 10.

EU HD, 1992. Council Directive 92/43/EEC of 21 May 1992 on the conservation of natural habitat and of wild fauna and flora. Offical Journal of the European Communities L 206: $7-50$.

Ferrington, L. C. J., 1995. Biodiversity of aquatic insects and other invertebrates in springs: introduction. Journal of the Kansas Entomological Society 68: 1-3.

Fischer, J., 1996. Kaltstenothermie-Einziger Schlüssel zum Verständnis der Krenobionten. Crunoecia 5: 91-96.

Fischer, J., F. Fischer, S. Schnabel, R. Wagner \& H. W. Bohle, 1998. Die Quellenfauna der Hessischen Mittelgebirgsregion. Besiedlungsstruktur, Anpassungsmechanismen und Habitatbindung der Makroinvertebraten am Beispiel von Quellen aus dem Rheinischen Schiefergebirge und der osthessischen Buntsandsteinlandschaft Studies in Crenobiology The biology of springs and springbrooks. Backhuys Publishers, Leiden, 181-199. 
Ford, T. D. \& H. M. Pedley, 1996. A review of tufa and travertine deposits of the world. Earth Science Reviews 41: 117-175.

Frazer, G. W., C. Canham \& K. Lertzman, 1999. Gap Light Analyzer (GLA), Version 2.0: Imaging Software to Extract Canopy Structure and Gap Light Transmission Indices From True-Colour Fisheye Photographs, Users Manual and Program Documentation. Simon Fraser University, Burnaby, British Columbia, and the Institute of Ecosystem Studies, Millbrook.

Gerecke, R., C. Meisch, F. Stoch, F. Acri \& H. Franz, 1998. Eucrenon-Hypocrenon ecotone and spring typology in the Alps of Berchtesgaden Studies in crenobiology. Blackhuys Publishers, Leiden: 167-182.

Gerecke, R., M. Cantonati, D. Spitale, E. Stur \& S. Wiedenbrug, 2011. The challenges of long-term ecological research in springs in the northern and southern Alps: indicator groups, habitat diversity, and medium-term change. Journal of Limnology 70: 168-187.

Glazier, D. S., 1991. The fauna of North American temperate cold springs: patterns and hypotheses. Freshwater Biology 26: 527-542.

Glazier, D. S., 2009. Springs. In Likens, G. E. (ed.), Encyclopedia of Inland Waters, Vol. 1., Academic Press Elsevier Oxford, UK: 734-755.

Glöer, P., 2002. Die Süßwassergastropoden Nord- und Mitteleuropas, Vol. 73. ConchBooks, Hackenheim.

Glöer, P. \& C. Meier-Brook, 2003. Süßwassermollusken-ein Bestimmungsschlüssel für die Bundesrepublik Deutschland, 13, neubearb. Aufl. edn. DJN, Hamburg.

Graf, W. \& A. Schmidt-Kloiber, 2002. Kursunterlagen (LV 801116) zum 'Spezialpraktikum Plecoptera-Steinfliegen, WS 2002/2003' [Identification keys to Plecoptera larvae]. University of Vienna, Vienna.

Hahn, H. J., 2000. Studies on classifying of undisturbed springs in Southwestern Germany by macrobenthic communities. Limnologica-Ecology and Management of Inland Waters 30: 247-259.

Hoffsten, P. O. \& B. Malmqvist, 2000. The macroinvertebrate fauna and hydrogeology of springs in central Sweden. Hydrobiologia 436: 91-104.

Hütter, L. A., 1994. Wasser und Wasseruntersuchung: Methodik, Theorie u. Praxis chemischer, chemisch-physikalischer, biologischer u. bakteriologischer Untersuchungsverfahren, 6., erw. und aktualisierte Aufl. edn. Salle, Frankfurt/Main.

Hynes, H. B., 1970. The Ecology of Running Waters, 1. Publ. edn. Liverpool University Press, Liverpool.

Illies, J. \& L. Botosaneanu, 1963. Problèmes et méthodes de la classification et de la zonation écologique des eaux courantes, considérées surtout du point de vue faunistique. SIL Mitteilung 12: 1-57.

Janeček, B., 2003. Kursunterlagen (LV 300428) zu 'Fauna Aquatica Austriaca'-Taxonomie und Ökologie aquatischer wirbelloser Organismen: Teil V Chironomidae (Zuckmücken) Larven.[Identification keys to chironomid larvae.]. University of Vienna, Vienna.

Karaman, G. S. \& S. Pinkster, 1977. Freshwater Gammarus species from Europe, North Africa and adjacent regions of Asia (Crustacea-Amphipoda). Bijdragen tot de Dierkunde 47: 1-97.
Kelly, D. W., J. T. A. Dick \& W. I. Montgomery, 2002a. The functional role of Gammarus (Crustacea, Amphipoda): Shredders, predators, or both? Hydrobiologia 485: 199-203.

Kelly, D. W., J. T. A. Dick \& W. I. Montgomery, 2002b. Predation on mayfly nymph, Baetis rhodani, by native and introduced Gammarus: Direct effects and the facilitation of predation by salmonids. Freshwater Biology 47: 1257-1268.

Kløve, B., P. Ala-aho, G. Bertrand, Z. Boukalova, A. Ertürk, N. Goldscheider, J. Ilmonen, N. Karakaya, H. Kupfersberger, J. Kvœrner, A. Lundberg, M. Mileusnić, A. Moszczynska, T. Muotka, E. Preda, P. Rossi, D. Siergieiev, J. Šimek, P. Wachniew, V. Angheluta \& A. Widerlund, 2011. Groundwater dependent ecosystems. Part I: Hydroecological status and trends. Environmental Science \& Policy 14: $770-781$.

Křoupalová, V., J. Bojková, J. Schenková, P. Pařil \& M. Horsák, 2011. Small-scale distribution of aquatic macroinvertebrates in two spring fens with different groundwater chemistry. International Review of Hydrobiology 96: 235-256.

Lencioni, V., L. Marziali \& B. Rossaro, 2011. Diversity and distribution of chironomids (Diptera, Chironomidae) in pristine Alpine and pre-Alpine springs (Northern Italy). Journal of Limnology 70: 106-121.

Lencioni, V., L. Marziali \& B. Rossaro, 2012. Chironomids as bioindicators of environmental quality in mountain springs. Freshwater Science 31: 525-541.

Lenntech, 2015. Langelier Saturation Index Calculator. In. http://www.lenntech.com/calculators/langelier/index/lange lier.htm Accessed 2nd February 2015.

Martin, P. \& M. Brunke, 2012. Faunal typology of lowland springs in northern Germany. Freshwater Science 31: 542-562.

Martin, P. \& L. Wischniowsky, 2014. Kalktuffquellen: Ein FFH-Lebensraum ohne Charakterarten in der Limnofauna? Deutsche Gesellschaft für Limnologie (DGL) Jahrestagung 2013: 72-76.

Merz, M. \& H. Zankle, 1991. The influence of the sheath on carbonate precipitation by cyanobacteria. Bollettino della Società Paleontologica Italiana-Special 1: 325-331.

Mezquita, F., G. Tapia \& J. Roca, 1999. Ostracoda from springs on the eastern Iberian Peninsula: ecology, biogeography and palaeolimnological implications. Palaeogeography, Palaeoclimatology, Palaeoecology 148: 65-85.

Minckley, W. L., 1963. The ecology of a spring stream: Doe Run, Meade County, Kentucky. Wildlife Monographs 11: 3-124.

Müller, J. H., 1984. Ökologie. Gustav Fischer (UTB), Jena.

Nilsson, A. N., 1996a. Aquatic insects of North Europe: A Taxonomic Handbook. Volume 1: Ephemeroptera, Plecoptera, Heteroptera, Neuroptera, Megaloptera, Coleoptera, Trichoptera, Lepidoptera. Apollo Books, Stenstrup.

Nilsson, A. N., 1996b. Aquatic Insects of North Europe: A Taxonomic Handbook. Volume 2: Odonata \& Diptera. Apollo Books, Stenstrup.

Odum, E. P., 1971. Fundamentals of Ecology, 3rd ed. Saunders, Philadelphia.

Omelková, M., V. Syrovátka, V. Křoupalová, V. Rádková, J. Bojková, M. Horsák, M. Zhai \& J. Helešic, 2013. Dipteran 
assemblages of spring fens closely follow the gradient of groundwater mineral richness. Canadian Journal of Fisheries and Aquatic Sciences 70: 689-700.

Pentecost, A., 1991. A new and interesting site for the calciteencrusted desmid Oocardium stratum Naeg. in the British Isles. British Phycological Journal 26: 297-301.

Pentecost, A., 2005. Travertine. Springer, Berlin.

Pentecost, A. \& H. Viles, 1994. A Review and Reassessment of Travertine Classification. Géographie physique et Quaternaire 48: 305-314.

Pitsch, T., 1993. Zur Larvaltaxonomie, Faunistik und Ökologie mitteleuropäischer Fließwasser-Köcherfliegen (Insecta, Trichoptera). Landschaftsentwicklung und Umweltforschung. Schriftenreihe des Fachbereichs Landschaftsentwicklung, Sonderheft S8, Technische Universität Berlin, pp. 316.

Pokorny, N., C. Fesl, M. Schagerl \& J. Waringer, 2010. factors structuring macroinvertebrate communities in a headwaterstream and its springs in the Upper Austrian limestone alps. River Research and Application. doi:10.1002/rra. 1474.

Pomeisl, E., 1953. Beiträge zur Limnologie der Wienerwaldbäche. Wetter und Leben II: 103-121.

Reynoldson, T. B. \& J. O. Young, 2000. A key to the British species of freshwater triclads (Turbellaria. Freshwater Biological Association Scientific Publications No, Paludicola): 58.

Roca, J. R. \& A. Baltanás, 1993. Ecology and distribution of Ostracoda in Pyrenean springs. Journal of Crustacean Biology 13: 165-174.

Rott, E., R. Hotzy, M. Cantonati \& D. Sanders, 2012. Calcification types of Oocardium stratum Nägeli and microhabitat conditions in springs of the Alps. Freshwater Science 31: 610-624.

Sanders, D. \& E. Rott, 2009. Contrasting styles of calcification by the micro-alga Oocardium stratum Naegeli 1849 (Zygnematophyceae) in two limestone-precipitating spring creeks of the Alps. Austrian Journal of Earth Sciences 102: 34-49.

Scarsbrook, M. R., J. Barquín \& D. P. Gray, 2007. New Zealand coldwater springs and their biodiversity. Science \& Technical Publishing, Department of Conservation, Wellington.

Sherwood, A. R. \& R. G. Sheath, 1998. Seasonality of macroalgae and epilithic diatoms in spring-fed streams in Texas, USA. Hydrobiologia 390: 73-82.

Stanford, J. A., J. V. Ward \& B. K. Ellis, 1994. Ecology of the alluvial aquifers of the Flathead River, Montana. In Danielopol, D. L., J. Gibert \& J. A. Stanford (eds.),
Groundwater Ecology. Academic Press, San Diego: 367-390.

Staudacher, K. \& L. Füreder, 2007. Habitat complexity and invertebrates in selected alpine springs (Schütt, Carinthia, Austria). International Review of Hydrobiology 92: 465-479.

Tchobanoglous, G. \& F. L. Burton, 1991. Wastewater Engineering Management 7: 1-4.

Thienemann, A., 1924. Hydrobiologische Untersuchungen an Quellen. Archiv für Hydrobiologie 14: 151-190.

Thienemann, A., 1934. Eine gesteinsbildende chironomide [Lithotanytarsus emarginatus Goethgebuer]. Zoomorphology 28: 480-496.

Townsend, C. R., 1989. The patch dynamics concept of stream community ecology. Journal of the North American Benthological Society 8: 36-50.

Travnitzky, R. \& R. A. Patzner, 2009. Beitrag zur Molluskenfauna (Gastropoda und Bivalvia) des Bundeslandes Salzburg, Österreich mit besonderer Berücksichtigung der Vertigo-Arten. Linzer biologische Beiträge 41: 2039-2050.

Van der Kamp, G., 1995. The hydrogeology of springs in relation to the biodiversity of spring fauna: a review. Journal of the Kansas Entomological Society 68: 4-17.

Verdonschot, R. E. M. \& J. A. Schot, 1987. Macrofaunal community types in helocrenal springs Annual Report 1986. Research Institute for Nature Management, Arnhem, Leersum and Texel: 85-103.

Ward, J. V., 1992. Aquatic Insect Ecology. 1. Biology and Habitat. Wiley, New York.

Waringer, J. \& W. Graf, 2011. Atlas der mitteleuropäischen Köcherfliegenlarven [Atlas of Central European Trichoptera larvae]. Mauch, Dinkelscherben.

Wimmer, R., A. Chovanec, O. Gruber, M. H. Moog \& D. Fink, 2000. Abiotic Stream Classification as a Basis for a Surveillance Monitoring Network in Austria in Accordance with the EU Water Framework Directive. Acta Hydrochimica et Hydrobiologica 28: 177-184.

Wright, J. S., 2000. Tufa accumulations in ephemeral streams: observations from the Kimberley, north-west Australia. Australian Geographer 31: 333-347.

Zollhöfer, J. M., 1997. Quellen-Die unbekannten Biotope im Schweizer Jura und Mittelland: Erfassen-BewertenSchützen. Bristol-Stiftung.

Zollhöfer, J. M., 1999. Spring Biotopes in Northern Switzerland: Habitat Heterogeneity, Zoobenthic Communities and Colonization Dynamics. Simon Fraser University, Burnaby. 